\title{
Cultivo in vitro con colágeno y fibroblastos humanos de un equivalente de mucosa oral de espesor total*
}

\section{In vitro culture with collagen and human fibroblasts of a full-thickness oral mucosa equivalent*}

\author{
S. González Mendez', L.M. Junquera Gutiérrez², I. Peña González³, V. García Díaz, \\ L. Gallego López 3 , E. García Pérez4, A. Meana Infiestas
}

\begin{abstract}
Resumen: Objetivos. El presente trabajo tiene por objetivo obtener, mediante cultivo in vitro, láminas de tejido oral en las que se pueda identificar las estructuras de una mucosa oral completa. La aplicación clínica del presente estudio permitiría, en determinados casos, la sustitución del empleo de injertos libres de piel o autólogos de mucosa oral por esta técnica. Material y Método. A partir de pequeñas biopsias de mucosa oral se hicieron cultivos primarios de queratinocitos. A partir de estos cultivos primarios se realizaron cultivos secundarios sobre una submucosa artificial constituida por colágeno y fibroblastos humanos. Se analizaron histológicamente sus características in vitro, y ulteriormente se procedió a la realización de injertos en ratones atímicos para conocer su comportamiento in vivo. Resultados. Los cultivos primarios fueron confluentes en un plazo mínimo de 10 días y máximo de 12 días, periodo similar al observado para la confluencia de los cultivos secundarios. El tiempo transcurrido desde la toma de la muestra hasta la obtención de una mucosa artificial completa osciló entre los 20 y los 22 días, mostrando las características histológicas de una mucosa normal. Tras 17 días de injerto en ratones inmunoincompetentes, sin ningún tipo de contingencia clínica, la caracterización histológica e inmunohistoquímica (citoqueratinas 13 y 19, colágeno IV y laminina) confirmó la similitud de la mucosa in vitro con la mucosa oral sana. Conclusión. Es posible mediante técnicas de cultivo in vitro la obtención de un equivalente de mucosa oral completa con colágeno y fibroblastos. Si bien esta mucosa muestra un importante grado de retracción, su manejo clínico es muy favorable.
\end{abstract}

Palabras clave: Cultivo in vitro; Colágeno; Fibroblastos; Mucosa Oral.

Recibido: 15.11 .07

Aceptado: 28.01 .09

*Premio "Beca de Investigación Básica, Dr. Gómez Iglesias"

\begin{abstract}
Objectives. The objective of this study was to obtain, by in vitro culture, sheets of oral tissue in which complete oral mucosa structures can be identified. Clinical application of the findings of this study will allow the replacement of free skin grafts or autologous oral mucosa grafts by this technique in certain cases.

Material and Method. Primary keratinocyte cultures were prepared from small biopsy samples of oral mucosa. Secondary cultures were prepared from these primary cultures on an artificial submucosa constituted by collagen and human fibroblasts. The cell cultures were analyzed histologically in vitro and then used for graft implants in athymic mice to study their behavior in vivo.

Results. The primary cultures were confluent within a minimum period of 10 days and maximum of 12 days, which is similar to the period that the secondary cultures required to reach confluence. The time from sampling to achieving a complete artificial mucosa ranged from 20 to 22 days. The artificial mucosa showed histologic characteristics of a normal mucosa. After 17 days of graft implantation in immunoincompetent mice without any clinical contingency, histologic and immunohistochemical characterization (cytokeratins 19 and 13, collagen IV, and laminin) confirmed the similarity of the mucosa in vitro to healthy oral mucosa.

Conclusion. A complete oral mucosa equivalent can be prepared with collagen and fibroblasts using in vitro culture techniques. Although this mucosa shows considerable retraction, its clinical handling is very favorable.
\end{abstract}

Key words: In vitro cultive; Collagen; Fibroblasts; Oral mucose.

1 Especialista en Cirugía Oral y Maxilofacial. Práctica Privada.

2 Profesor Titular Vinculado de Cirugía Oral y Maxilofacial. Universidad de Oviedo. Hospital Universitario Central de Asturias. España

3 Médico Residente. Servicio de Cirugía Oral y Maxilofacial. Hospital Universitario Central de Asturias. España

4 Bióloga. Banco de Tejidos.

5 Coordinador del Banco de Tejidos.

Centro Comunitario de Sangre y Tejidos del Principado de Asturias. Oviedo. España

\section{Correspondencia:}

L.M. Junquera

Universidad de Oviedo. Escuela de Estomatología

Catedrático José Serrano s/n

33009 Oviedo. España

E-mail: Junquera@uniovi.es 


\section{Introducción}

En 1975 Rheinwald y Green, describieron un método para cultivar láminas de tejido epitelial in vitro utilizando como células cebadoras una capa de fibroblastos de ratón (células 3T3) letalmente irradiados, en un medio que contenía suero fetal-bovino y factores de crecimiento celular. Consiguieron la primera línea de queratinocitos a partir de un teratoma de ratón. ${ }^{1}$ Dos años más tarde publicaron la técnica para la obtención de queratinocitos humanos cultivados in vitro. ${ }^{2}$ El epitelio humano autólogo obtenido mediante cultivo ha sido usado con éxito desde 1980 como cobertura permanente de grandes defectos cutáneos. ${ }^{3-6}$ Es interesante remarcar que el epitelio trasplantado conserva las características del sitio donante. Actualmente esta técnica constituye una reconocida forma de tratamiento en grandes quemados. ${ }^{5}$

En 1990 De Luca y cols. ${ }^{4}$ utilizaron clínicamente mucosa oral obtenida mediante cultivo de queratinocitos procedentes del paladar, para el tratamiento de defectos gingivales de origen periodontal, demostrando la posibilidad de obtener grandes cantidades de epitelio cultivado capaces de mantener las propiedades de la zona donante, a partir de una biopsia de $1-3 \mathrm{~mm}^{2}$. Ragoebar y cols., ${ }^{7}$ utilizaron la técnica de cultivo in vitro de mucosa oral para cubrir defectos causados durante la realización de vestibuloplastias. En su trabajo, una mitad del área denudada fue cubierta con mucosa obtenida de manera convencional del paladar como injerto libre, y la otra mitad con mucosa palatina obtenida por cultivo. A los tres meses de la cirugía, la mucosa que recubría ambas mitades era similar a la mucosa palatina, sin objetivarse reacción contra el injerto obtenido mediante cultivo in vitro. Mediante microscopía de luz y electrónica, se demostró que ambos injertos formaban una mucosa totalmente diferenciada, comparable ultraestructuralmente con la del paladar.

Sin embargo, las dificultades para el transporte del cultivo, su fijación al lecho receptor, y su permanencia en el mismo ante los traumatismos del medio oral, limitan la aplicación clínica de esta técnica, por el exclusivo hecho de la fragilidad inherente a un tejido exclusivamente epitelial. Diversos autores han desarrollado modelos cutáneos en cultivo de espesor total, utilizando varios tipos de soporte dérmico, ${ }^{8-12}$ demostrando un mejor comportamiento clínico de los mismos, con respecto al observado en los cultivos epiteliales aislados. En relación con la mucosa oral, las investigaciones en este sentido, son mas escasas. ${ }^{13,14}$ El presente trabajo tiene los siguientes objetivos: 1. Elaborar una mucosa oral completa utilizando como soporte epitelial un gel de colágeno I y fibroblastos humanos. 2. Evaluar su comportamiento clínico mediante injerto en ratones inmunoincompetentes. 3. Caracterizar inmunohistoquímicamente su comportamiento tras 17 días de injerto.

\section{Material y método}

\section{Cultivo primario de queratinocitos humanos}

Se obtuvieron tres muestras de la mucosa oral en pacientes intervenidos en el Quirófano Ambulatorio del Servicio de Cirugía Oral y Maxilofacial de nuestro Centro, haciendo coincidir la toma de la

\section{Introduction}

In 1975, Rheinwald and Green described a method for culturing sheets of epithelial tissue in vitro using a layer of lethally irradiated mouse fibroblasts (3T3 cells) as primer cells in a medium containing fetal bovine serum and cellular growth factors. The first line of keratinocytes was obtained from a murine teratoma. ${ }^{1}$ Two years later these authors reported the technique for obtaining human keratinocytes by in vitro culture. ${ }^{2}$ Autologous human epithelium obtained by culture has been used successfully since 1980 as a permanent covering for large skin defects. ${ }^{3-6}$ It is interesting to note that the transplanted epithelium conserves the characteristics of the donor site. This technique is currently a recognized form of treatment for major burns. 5

In 1990, De Luca et al.4 used oral mucosa obtained by culturing keratinocytes from the palate in clinical practice for the treatment of gingival defects of periodontal origin. They demonstrated that large amounts of cultured epithelium capable of maintaining the properties of the donor zone could be prepared from a biopsy sample of 1-3 $\mathrm{mm}^{2}$. Ragoebar et al. ${ }^{7}$ used the in vitro culture technique for oral mucosa to cover defects that occur during vestibuloplasty. In their study, half of the denuded area was covered with mucosa obtained conventionally from the palate as a free graft, and other half with palatal mucosa obtained by culture. At three months of surgery, the mucosa covering both halves was similar to the palatal mucosa; no reaction against the graft obtained by culture in vitro was evident. Light microscopy and electron microscopy demonstrated that both grafts formed a fully differentiated mucosa that was ultrastructurally consistent with the palate.

However, difficulties of culture transport, fixation to the receptor bed, and permanence in the receptor bed in response to trauma in the oral medium limit the clinical applicability of this technique due simply to the intrinsic fragility of exclusively epithelial tissue. Various authors have developed full thickness cutaneous models in culture using several types of skin substrate ${ }^{8-12}$ that exhibit better clinical behavior than isolated epithelial cultures. Fewer investigations of this type have been made in relation to oral mucosa. 13,14 The objectives of the present study were: 1. Prepare a complete oral mucosa using a gel of collagen I and human fibroblasts as the epithelial substrate. 2. Evaluate the clinical behavior of the mucosa by graft implantation in immunoincompetent mice. 3. Characterize the behavior of the mucosa immunohistochemically 17 days after graft implantation.

\section{Material and method}

\section{Primary culture of human keratinocytes}

Three samples of oral mucosa were obtained in patients intervened in the outpatient surgery of the Oral and Maxillofacial Surgery Department of our center during an inter- 
muestra con el tratamiento quirúrgico bajo anestesia local, de una patología oral no maligna. La superficie de las muestras fue en todos los casos inferior a $0,25 \mathrm{~cm}^{2}$. Todos los pacientes dieron su conformidad por escrito para la toma de la muestra, previa información documentada sobre la naturaleza del estudio. El procesamiento de las muestras, se realizó en las 4 horas siguientes a su recogida. Se dividieron mecánicamente hasta obtener fragmentos del menor tamaño posible. El material resultante se sometió a un proceso de digestión enzimática en $4 \mathrm{ml}$ de Tripsina/EDTA (T/E) durante 30 minutos a $37^{\circ} \mathrm{C}$ y bajo agitación suave. Se recogió el sobrenadante, que fue centrifugado durante 10 minutos a $1400 \mathrm{rpm}$, de manera que las células suspendidas en el líquido se depositaran en el fondo del tubo de ensayo. El pellet resultante se diluyó en $0,5 \mathrm{ml}$ de medio de cultivo para contar las células obtenidas. Las células obtenidas se cultivaron, a una densidad de entre 5.000 y 12.000 $\mathrm{cel} / \mathrm{cm}^{2}$ en placas de cultivo celular en presencia de fibroblastos de ratón (3T3; European Collection of Animal Cell culture 85022108) letalmente irradiados. Este medio se cambió cada 3 días. A partir del primer cambio se le añadieron al medio EGF (Factor de Crecimiento Epidérmico, Austral Biologicals). Los cultivos se mantuvieron en estufa con una atmósfera húmeda con un $5 \%$ de $\mathrm{CO}_{2}$ a $37^{\circ} \mathrm{C}$.

\section{Preparación de una submucosa artificial compuesta por colágeno y fibroblastos humanos}

Se utilizó como fuente de colágeno, el obtenido a partir de tendones disecados de cola de rata Wistar. Éstas se mantuvieron en alcohol de $70^{\circ}$ durante 2 horas y posteriormente se procedió a realizar la disección mediante técnica estéril. Una vez retirada la piel, los haces tendinosos de la cola se fueron separando cuidadosamente eliminando los vasos sanguíneos para asegurar la obtención de colágeno puro. Una vez individualizados, los tendones se dividieron en pequeñas piezas y se lavaron 2 veces en agua destilada. Posteriormente se secaron entre gasas estériles. El material así obtenido fue pesado y se disolvió en una proporción de 0,01\% de ácido acético estéril (100 ml de solución por gramo de tejido). La solución conteniendo los haces tendinosos previamente preparados se incubó a $4^{\circ} \mathrm{C}$ bajo agitación suave un mínimo de 48 horas. Una vez completado el proceso de digestión la solución se centrifugó durante 30 minutos a $30.000 \mathrm{G}$ y el pellet resultante fue liofilizado y almacenado en tubos estériles. La pureza del colágeno obtenido se estudió mediante electroforesis en gel de poliacrilamida.

Los fibroblastos utilizados, se obtuvieron a partir de prepucios humanos de pacientes pediátricos intervenidos de fimosis en nuestro Centro, previo permiso de sus representantes legales. Estas muestras se fragmentaron mecánicamente y posteriormente fueron sometidas a un proceso de digestión enzimática con T/E bajo agitación mecánica. Cada 30 minutos se sustituyó la T/E utilizada por otra fresca y se centrifugaron durante 10 minutos a $1.400 \mathrm{rpm}$ con el fin de recuperar las células obtenidas de la muestra. Se procedió a la siembra celular a una densidad de $100.000 \mathrm{cel} / \mathrm{cm}^{2}$ en un medio de cultivo para fibroblastos. Cuando las células de este cultivo fueron confluentes se lavó el frasco de cultivo 2 veces con T/E, tras lo cual fue incubado a $37^{\circ} \mathrm{C}$ con T/E hasta que las células se despegaron del mismo. Se recuperaron las células y se sembraron en otros frascos de cultivo a una densidad de entre 5.000 y $10.000 \mathrm{cél} / \mathrm{cm}^{2}$ vention for a benign oral pathology with local anesthesia. The surface area of the samples in every case was less than $0.25 \mathrm{~cm}^{2}$. All the patients gave written consent to allow the sample to be collected after receiving documented information about the nature of the study. The samples were processed within 4 hours of collection. They were divided mechanically until fragments of the smallest possible size were obtained. The resulting material was submitted to enzymatic digestion in $4 \mathrm{ml}$ of Trypsin/EDTA (T/E) during $30 \mathrm{~min}$ utes at $37^{\circ} \mathrm{C}$ and with gentle agitation. The supernatant was collected and centrifuged for 10 minutes at $1400 \mathrm{rpm}$, so that the cells suspended in fluid were deposited at the bottom of the test tube. The resulting pellet was diluted in 0.5 $\mathrm{ml}$ of culture medium to count the cells obtained. The cells obtained were cultured at a density of 5,000 to 12,000 cells $/ \mathrm{cm} 2$ on cell culture plates in the presence of lethally irradiated mouse fibroblasts (3T3; European Collection of Animal Cell culture 85022108). The medium was changed every 3 days. After the first change, EGF (Epidermal Growth Factor, Austral Biologicals) was added to the medium. The cultures were kept in an oven with a humid atmosphere and $5 \% \mathrm{CO}_{2}$ at $37^{\circ} \mathrm{C}$.

Preparation of an artificial submucosa consisting of collagen and human fibroblasts

The collagen source used was obtained from dissected tendons of Wistar rat tail. The tails were kept in $70^{\circ}$ alcohol for 2 hours and then dissected using sterile technique. Once the skin was removed, the tendinous bundles of the tail were separated carefully and the blood vessels were eliminated to ensure that pure collagen was obtained. Once the tendons were individualized, they were divided into small pieces and washed twice in distilled water. Later the tendons were dried between sterile gauze pads. The material obtained was weighed and dissolved in sterile acetic acid in a proportion of $0.01 \%(100 \mathrm{ml}$ of solution per gram of tissue). The solution containing the previously prepared tendinous bundles was incubated at $4^{\circ} \mathrm{C}$ with gentle agitation for at least 48 hours. Once the digestion process was complete, the solution was centrifuged for 30 minutes at 30,000 G and the resulting pellet was lyophilized and stored in sterile tubes. The purity of the collagen obtained was analyzed by electrophoresis on polyacrylamide gel.

The fibroblasts used were obtained from human foreskins removed from pediatric patients treated for phimosis at our center, after previously obtaining permission from their legal guardians. These samples were fragmented mechanically and then digested enzymatically with $T / E$ while being mechanically agitated. Every 30 minutes the T/E medium was replaced with fresh medium. Finally the solution was centrifuged during 10 minutes at 1,400 rpm to recover the cells from the sample. The cells were seeded at a density of 100,000 cells $/ \mathrm{cm}^{2}$ in a fibroblast culture medium. When the cells of this culture were confluent, the culture bottle was washed twice with $T / E$ and then incubated at $37^{\circ} \mathrm{C}$ with $T / E$ 
(cultivo secundario). Los fibroblastos se mantuvieron mediante cultivos sucesivos o bien se congelaron en medio de congelación de fibroblastos para posteriores usos. Para la preparación del gel de colágeno y fibroblastos se utilizaron $0,8 \mathrm{ml}$ de solución de colágeno con 0,1 $\mathrm{ml}$ de $\mathrm{NaOH}$ y $0,1 \mathrm{ml}$ de Ham-F12 10X. A esta solución se añadieron los fibroblastos a una concentración aproximada de entre 30.000 a $50.000 \mathrm{cel} / \mathrm{ml}$. Para una placa de $25 \mathrm{~cm}^{2}$ se utilizaron $5 \mathrm{ml}$ de gel. El material obtenido por cultivo según la técnica previamente descrita, se estudió histológicamente mediante fijación en formol al 10\% y tinción con hematoxilina- eosina.

\section{Experimentación animal}

Se procedió al injerto de los cultivos obtenidos en tres ratones atímicos (BALD/ c nu/un ) según la técnica descrita por Barrandon y cols. ${ }^{15}$ (Fig. 1). A los 17 días del injerto, se procedió al sacrificio del animal y biopsia del tejido injertado para su análisis histológico. El análisis inmunohistoquímico se realizó con kits para citoqueratinas 13 y 19, colágeno IV y laminina. En la figura 2 se recoge de manera esquemática, las principales etapas del trabajo.

\section{Resultados}

\section{Cultivos primarios}

A los tres o cuatro días del cultivo fue posible comprobar el inicio de la formación de colonias de queratinocitos, rodeadas por fibroblastos 3 T3. A partir de la primera semana de cultivo se objetivó el rechazo de estos últimos hacia la periferia de las colonias, disminuyendo de forma considerable su número. En el momento de la confluencia de las colonias epiteliales no fue posible observar la presencia de fibroblastos $3 T 3$ (Fig. 3). Los cultivos primarios fueron confluentes en un plazo mínimo de 10 días y máximo de 12 días, y en este momento se procedió a la realización del cultivo secundario sobre el gel de colágeno y fibroblastos elaborado. Se obtuvieron aproximadamente 1000 células por cada célula cultivada en este plazo.

\section{Cultivos secundarios}

Los cultivos secundarios también fueron confluentes a los 10 días, momento en el que fueron fijados para su estudio histológi-

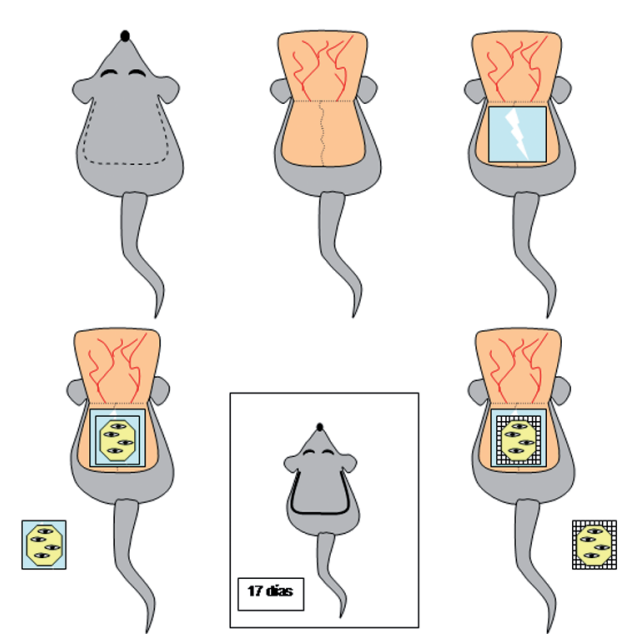

Figura 1. Representación gráfica de la técnica descrita por Barrandon y cols. para la realización de injertos dorsales en ratones atímicos.

Figure 1. Graphic representation of the technique described by Barrandon et al. for dorsal graft implantation in athymic mice.

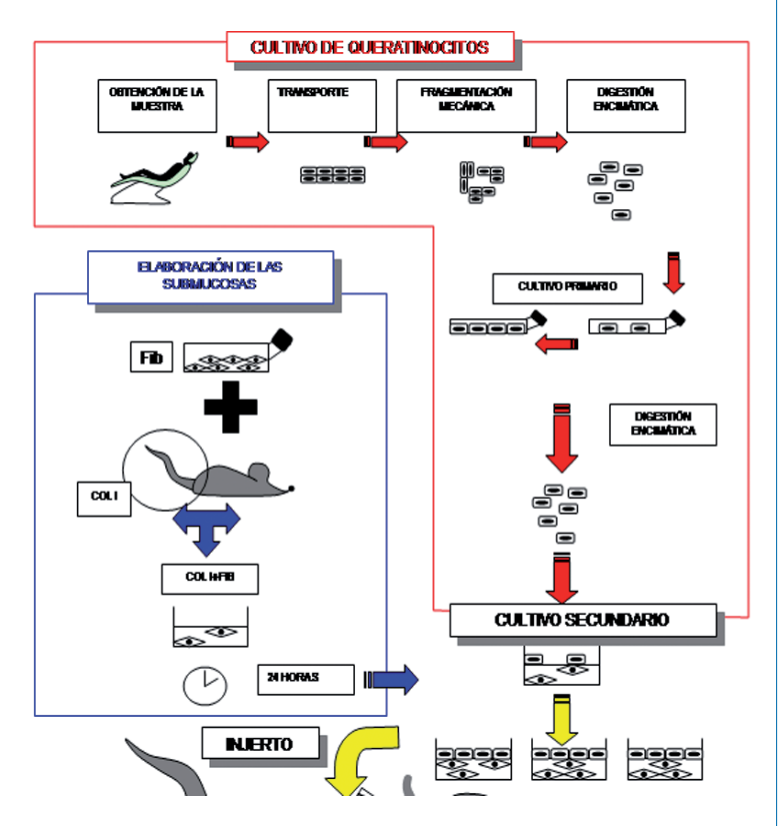

Figura 2. Esquema representativo de las principales fases metodológicas del estudio.

Figure 2. Diagram of the main methodologic phases of the study. until the cells separated from the substrate. The cells were recovered and seeded in other culture bottles at a density of 5,000 to $10,000 \mathrm{cells} / \mathrm{cm}^{2}$ (secondary culture). The fibroblasts were maintained by successive cultures or were frozen in fibroblast freezing medium for later use.

The collagen and fibroblast gel was prepared using 0.8 $\mathrm{ml}$ of collagen solution with $0.1 \mathrm{ml}$ of $\mathrm{NaOH}$ and $0.1 \mathrm{ml}$ of Ham-F12 10X. Fibroblasts were added to this solution at an approximate concentration of 30,000 to 50,000 cells $/ \mathrm{ml}$. For a $25-\mathrm{cm}^{2}$ plate, $5 \mathrm{ml}$ of gel was used. The material obtained by culture according to the technique described above was studied histologically by fixation in $10 \%$ formalin and staining with hematoxylin-eosin.

\section{Animal experimentation}

The cultured cells were grafted in three athymic mice (BALD/ c nu/un) following the technique described by Barrandon et al. 15 (Fig. 1). At 17 days of graft implantation, the animal was killed and a biopsy was made of the graft tissue for histologic analysis. Immunohistochemical analysis was made with kits for cytokeratins 13 and 19, collagen IV, and laminin. A diagram of the main stages of work is shown in figure 2.

\section{Results}

\section{Primary cultures}

At three or four days of culture, incipient formation of keratinocyte colonies surrounded by 3 T3 fibroblasts was observed. Starting in the first week of culture, fibroblasts were displaced to the periphery of the colonies and their number diminished considerably. When the epithelial colonies were confluent, the 3T3 fibroblasts were not visible (Fig. 3). The primary cultures were confluent within a minimum peri- 
co. Durante este tiempo, y desde los primeros momentos del cultivo, se pudo observar la existencia de un rápido proceso de retracción de los queratinocitos sobre el gel de colágeno. En todo caso, el tiempo transcurrido desde la toma de la muestra hasta la obtención de una mucosa artificial completa con colágeno y fibroblastos humanos osciló entre los 20 y los 22 días.

Al analizar histológicamente el material obtenido pudimos apreciar la existencia de un epitelio continuo de células cuboideas similares a las que podemos encontrar en la capa basal del epitelio oral normal. En algunas zonas, el epitelio presentaba dos o tres filas de células, pero ningún signo de queratinización (Fig. 4). Subepitelialmente, se podía reconocer la existencia de fibroblastos en forma estrellada y con uniones entre ellos. También resultaba evidenciable la presencia de haces que se tiñen de forma semejante a los del colágeno distribuidos de forma anárquica y de un pobre entramado vascular.

\section{Experimentación animal}

Los animales se mantuvieron vivos durante 17 días. Durante este tiempo ningún ratón presentó complicaciones directamente relacionadas con el acto quirúrgico ni ajenas a éste. El análisis microscópico a pequeño aumento de la unión entre el tejido injertado y los tejidos de ratón, reveló la continuidad de la misma. En la porción epitelial se advierten múltiples capas de células. A mayor aumento, fue posible apreciar que las capas celulares están organizadas de forma similar a una mucosa oral no queratinizada normal. En algunas áreas, se objetivó una cierta desorganización del epitelio (Fig. 5). En ninguno de los injertos se observó queratinización, poniéndose de manifiesto la presencia de núcleos incluso en las capas más distales de queratinocitos. En el tejido subepitelial era apreciable la abundante presencia de fibroblastos proliferantes en el seno de los geles. No fue posible reconocer la presencia de papilas, aunque si se aprecian en algunas zonas ligeras invaginaciones de tejido epitelial en la submucosa.

La tinción frente a citoqueratina 13 fue positiva en todas las capas del epitelio, mientras que para la citoqueratina 19 observamos la existencia de áreas limitadas de inmunomarcaje. Mientras que frente al colágeno IV se observó una marcada tinción en la submucosa y en las capas más basales de la porción epitelial, el inmu-

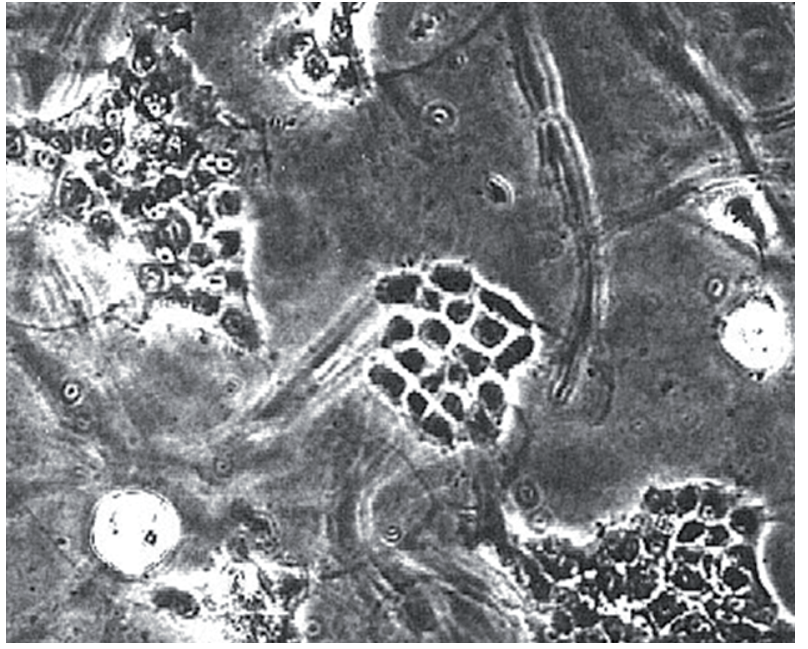

Figura 3. Imagen al microscopio invertido de contraste de fase, de la formación de las colonias de queratinocitos durante el cultivo primario.

Figure 3. Phase-contrast inverted microscopy image of keratinocyte colony formation during the primary culture.

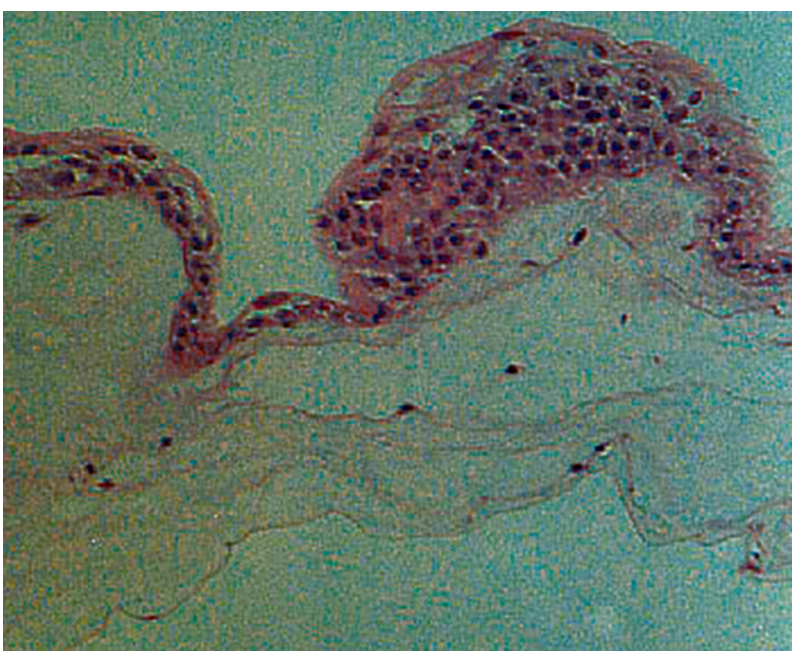

Figura 4. Microfotografía de la mucosa oral obtenida in vitro

Fure 4. Microphotography of the oral mucosa obtained in vitro before grafting in mice (HE $\times 40)$. od of 10 days and a maximum period of 12 days. At this moment the secondary culture was made on the collagen and fibroblast gel prepared. The yield was approximately 1000 cells per cell cultured in this period.

\section{Secondary cultures}

The secondary cultures also were confluent at 10 days, when they were fixed for histologic study. At this time and from the first moments of culture, a rapid process of the keratinocyte retraction was observed on the collagen gel. In any case, the time from sampling until a complete artificial mucosa was obtained from collagen and human fibroblasts ranged from 20 to 22 days.

Histologic analysis of the material obtained found a continuous epithelium of cuboid cells similar to what we find in the basement layer of normal oral epithelium. In some zones, the epithelium had two or three rows of cells, but no sign of keratinization (Fig. 4). Stellate fibroblasts adhered to each other were recognized subepithelially. The presence of anarchically distributed bundles exhibiting collagen-like staining properties and a rudimentary vascular network also was evident.

\section{Animal experimentation}

The animals were kept alive for 17 days. During this time no mouse presented complications, whether directly related to surgery or other. Microscopic study at low magnification of the interface between the graft tissue and native mouse tissues detected continuity. The epithelial portion exhibited several layers of cells. At higher magnification, cellular layers organized similarly to normal unkeratinized oral mucosa were apparent. In some areas, epithelial disorganization was evident (Fig. 5). None of the grafts exhibited keratinization; nuclei were evident even in distal keratinocyte layers. In the subepithelial tissue abundant proliferating fibroblasts were 
nomarcaje para la laminina se localizó en la porción basal del epitelio (Fig. 6).

\section{Discusión}

Los primeros intentos de cultivo in vitro de queratinocitos presentaban como grandes inconvenientes: 1. La importante retracción que se observaba al despegar el tejido cultivado del frasco de cultivo. 2. La extrema delgadez del injerto, fruto de su exclusiva constitución epitelial. 3. La fragilidad del tejido una vez injertado que podría conllevar su precoz pérdida. Todos ellos están relacionados directamente con la ausencia de un soporte adecuado para la constitución de una membrana basal normal y la completa y adecuada diferenciación del tejido epitelial. ${ }^{16}$

Con el fin de solventar estos problemas, las investigaciones se dirigieron a dotar a los cultivos de células epiteliales de un soporte conjuntivo. ${ }^{17,18}$ Los distintos autores propusieron diferentes sistemas que podemos agrupar en: 1. Uso de dermis criopreservada de cadáver, transplantándola previamente al lecho receptor del injerto. ${ }^{19}$ 2. Empleo de estructuras sintéticas tridimensionales de materiales reabsorbibles como soporte de fibroblastos autólogos, o como dermis acelular. ${ }^{20}$ 3. Síntesis in vitro de un soporte que posibilitara el crecimiento y desarrollo de fibroblastos humanos, realizado con las proteínas que constituyen la dermis. ${ }^{21}$ En el momento actual, es este último sistema el que concita los mayores esfuerzos investigadores por parte de la comunidad científica. Así, se han utilizado diferentes geles sintetizados a partir de proteínas humanas como colágeno tipo I, glicosaminoglicanos y fibrina. ${ }^{22}$ Otra línea de trabajo va encaminada a obtener una base proteica conteniendo fibroblastos vivos. Es conocido el hecho de que en el desarrollo normal de los tejidos epiteliales la síntesis de las proteínas de la membrana basal (laminina y colágeno IV) corresponde a los queratinocitos, pero el otro componente de la membrana basal, las fibrillas de anclaje, no se sintetizan en ausencia de los fibroblastos de la dermis. Se ha podido demostrar que los fibroblastos humanos mantenidos en un gel de fibrina son capaces de sintetizar las mismas sustancias que in vivo, y por tanto servir como soporte al crecimiento de los queratinocitos. ${ }^{23}$ En nuestro estudio, la elaboración de la submucosa de colágeno,

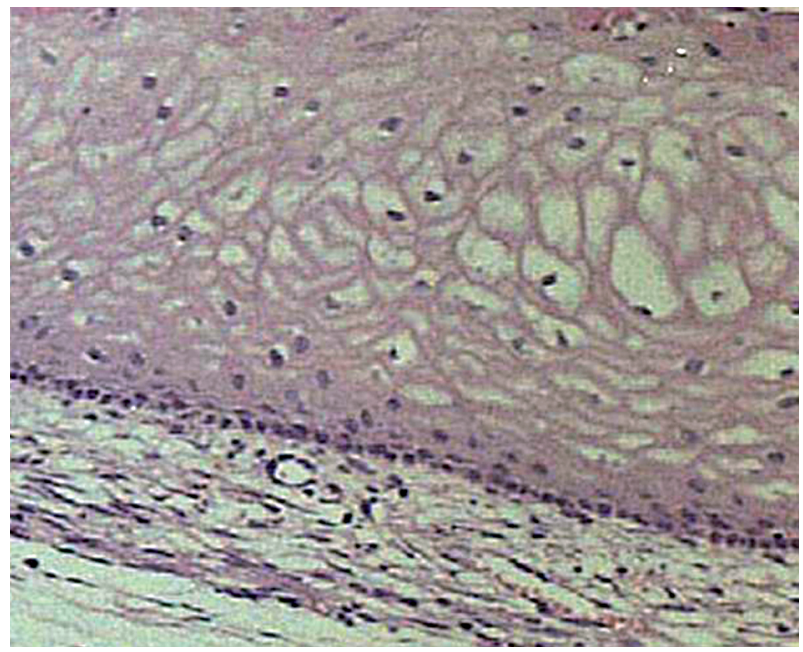

Figura 5. Microfotografía correspondiente a la mucosa a los 17 días Figure 5. Microphotography of the mucosa 17 days after implanting the graft in immunoincompetent mice (HE x 100).

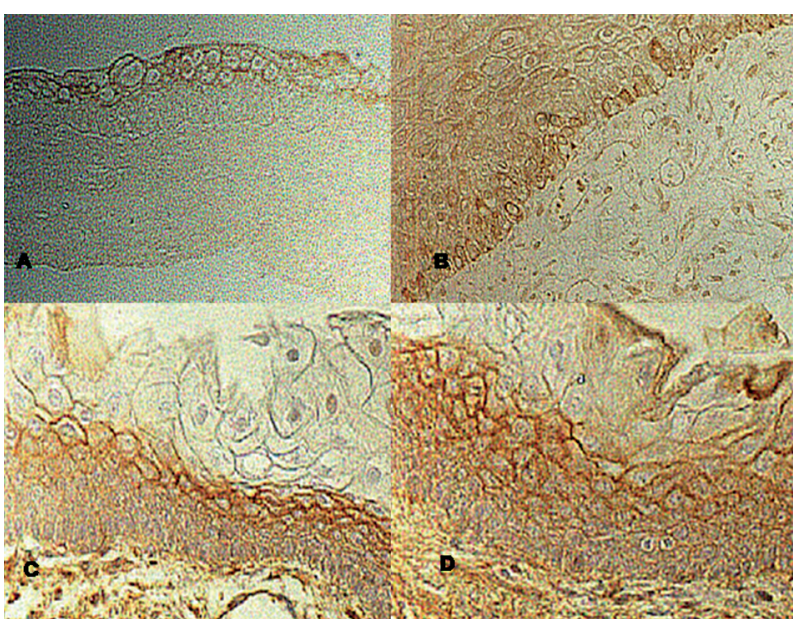

Figura 6. Tinciones inmunohistoquímicas tras el injerto. A Citoqueratina-13. B Citoqueratina-19. C Colágeno IV. D Laminina Figure 6. Immunohistochemical staining after graft implantation. A Cytokeratin-13. B. Cytokeratin-19. C. Collagen IV. D. Laminin. appreciable in the gel matrix. Papillae were not recognized, although slight invaginations of the epithelial tissue were seen in some areas in the submucosa.

Cytokeratin 13 staining was positive in all the layers of the epithelium, whereas cytokeratin 19 staining showed only limited areas of immune labeling. Immune labeling of collagen IV produced marked staining of the submucosa and most basal layers of the epithelial portion, but laminin staining was concentrated in the basal portion of epithelium (Fig. 6).

\section{Discussion}

Early attempts at in vitro culture of keratinocytes were plagued by major drawbacks: 1. 1. Marked retraction was observed when the cultured tissue was separated from the culture bottle. 2. Grafts are extremely thin to their exclusively epithelial constitution. 3. The grafted tissue is fragile and early graft loss is possible. These drawbacks are directly related to the absence of an adequate substrate for the constitution of a normal basement membrane and the complete and adequate differentiation of epithelial tissue. ${ }^{16}$

In order to resolve these problems, investigations have focused on developing epithelial cell cultures with connective support. ${ }^{17,18}$ Different authors have proposed a variety of systems that can be grouped as: 1. Use of cryopreserved cadaver dermis transplanted onto the graft receptor bed. ${ }^{19}$ 2. Use of three-dimensional synthetic structures of absorbable materials as an autologous fibroblast substrate or as acellular dermis. ${ }^{20} 3$. Synthesis in vitro of a substrate of dermal proteins for the growth and development of human fibroblasts. ${ }^{21}$ At present, in vitro synthesis is enjoying the most intensive investigative efforts of the scientific community. A number of gels have been synthesized from human proteins, such as collagen type I, glycosaminoglycans, and fibrin. ${ }^{22}$ Another line of investiga- 
fue técnicamente sencilla y rápida pero generaba una importante retracción de los cultivos, que se inicia en las primeras 48 del cultivo secundario y representa al final una importante reducción en el tamaño del injerto a utilizar. Similar observación ya fue enfatizada por otros autores que han producido mucosa oral completa utilizando el colágeno como proteína de soporte. ${ }^{22} \mathrm{Sin}$ embargo, el despegamiento de los cultivos realizados sobre gel de colágeno y fibroblastos humanos, resulta extraordinariamente fácil, incluso en algunos casos este despegamiento se produce de forma espontánea. La gran resistencia del soporte submucoso nos permitió, en todo momento, una manipulación perfecta, sin precisar de ningún cuidado especial.

En el estudio microscópico de la mucosa oral tras su injerto pudimos identificar la existencia de pequeñas áreas desestructuradas, con degeneración hidrópica. Aunque algunos autores, 24 defienden una desfavorable evolución del injerto en estas zonas, la caracterización inmunohistoquímica de las mismas en nuestro trabajo no mostró diferencias con respecto a la mucosa cultivada sin alteraciones estructurales. El aspecto microscópico de la submucosa permitió observar la existencia de una pobre vascularización subepitelial constituida por vasos de pequeño calibre, que, sin embargo, no condicionó ni limitó el desarrollo de la capa epitelial. Es posible que el colágeno, a diferencia de la fibrina, no promueva la incorporación de nuevos vasos hacia el área lesionada.

La citoqueratina 13 (K13), se expresan típicamente en las células suprabasales del epitelio oral, tanto queratinizado como no queratinizado, manifestando también en las células de la mucosa oral fetal una fuerte positividad. En nuestras muestras también mostró una fuerte positividad, tal vez justificable por el proceso de diferenciación en el que se encontraban, tras 17 días de injerto. La citoqueratina 19 (K19), es un marcador típico de la mucosa no queratinizada, que también se expresó en nuestras preparaciones, incluyendo a los queratinocitos situados en las capas suprabasales en las áreas de epitelio más desorganizado.

Según diversos autores, 22,25 a las tres semanas del cultivo, se produce una normalización completa de la estructura de la membrana basal. Esto supone un depósito regular de colágeno IV y laminina, y contactos estables epitelio-tejido conjuntivo, establecidos por la intermediación de la integrina alfa-6- beta-4. Esta regularización es fundamental para obtener un fenotipo normal en la mucosa artificial. En nuestro trabajo, tras 17 días de injerto, la tinción inmunohistoquímica fue positiva frente al colágeno IV y laminina.

En definitiva, el presente estudio pone en evidencia que el gel de colágeno supone un buen soporte para el crecimiento de los fibroblastos y de los queratinocitos orales. La síntesis del gel es muy sencilla y predecible. Su manejo es extraordinariamente fácil y no precisa demasiadas precauciones. No obstante, la retracción que se produce es muy importante, lo que dificulta la obtención de una cantidad grande de tejido, que es uno de los objetivos de la técnica. A pesar de esto, también hemos observado que, este proceso de retracción se detiene en el momento del injerto, conservando el tejido injertado su diámetro en el momento del sacrificio de los animales. tion has the objective of obtaining a protein base containing live fibroblasts. It is known that in the normal development of epithelial tissues the synthesis of basement membrane proteins (laminin and collagen IV) is a keratinocyte function, but the other component of the basement membrane, anchorage fibrils, is not synthesized in the absence of fibroblasts of the dermis. It has been demonstrated that human fibroblasts maintained in fibrin gel are capable of synthesizing the same substances as in vivo, making it a possible substrate for keratinocyte growth. ${ }^{23}$ The preparation of submucosa from collagen in our study was technically simple and quick, but it was accompanied by intense culture retraction that began in the first 48 hours of the secondary culture and ultimately resulted in a large reduction in the size of the usable graft. A similar observation has been highlighted by other authors who have produced complete oral mucosa using collagen as the protein substrate. ${ }^{22}$ Nevertheless, it was extraordinarily easy to separate the cultures made on a gel of collagen and human fibroblasts and, in some cases, the epithelial layer separated spontaneously. The resistance of the submucosal substrate allowed perfect handling at any time, without requiring any special care.

In the microscopic study of the oral mucosa obtained after grafting, we identified small destructured areas with hydropic degeneration. Although some authors 24 claim that the graft evolution of destructured areas is unfavorable, immunohistochemical characterization of these areas in our study did not show any differences with respect to the cultured mucosa that did not have structural alterations. Microscopic examination of the submucosa revealed the existence of rudimentary subepithelial vascularization consisting of small caliber vessels, which did not condition or limit the development of the epithelial layer. It is possible that collagen, unlike fibrin, does not favor the incorporation of new vessels in the injured area.

Cytokeratin 13 (K13) is typically expressed by the suprabasal cells of the oral epithelium, keratinized or unkeratinized, and also was strongly positive in the cells of the fetal oral mucosa. Cytokeratin 17 also showed strong positivity in our samples, perhaps attributable to the differentiation process that the tissue was experiencing 17 days after graft implantation. Cytokeratin 19 (K19) is a typical marker of unkeratinized mucosa that also was expressed in our preparations, including in keratinocytes located in the suprabasal layers of the areas of more disorganized epithelium.

According to several authors, ${ }^{22,23}$ the structure of the basement membrane is completely normalized at three weeks of culture. This consists of a regular deposition of collagen IV and laminin and stable contacts between the epithelium and connective tissue, as a consequence of the mediation of alpha-6-beta-4 integrin. This regularization is fundamental in obtaining an artificial mucosa with a normal phenotype. In our study, immunohistochemical staining was positive for collagen IV and laminin 17 days after graft 


\section{Agradecimientos}

A la Sociedad Española de Cirugía Oral y Maxilofacial e industrias Tarma S.A., por el apoyo prestado para la realización de este trabajo (Beca de Investigación Básica Dr. Gómez Iglesias).

A la Ficyt (Eva García Pérez) y MBA (Verónica García Díaz) por su apoyo técnico.

\section{Bibliografía}

1. Rheinwald J, Green H. Serial cultivation of strain of human epidermal keratinocytes: the formation of keratinizing colonies from single cells. Cell 1975;6:33144.

2. Green $\mathrm{H}$, Kehinde $\mathrm{O}$, Thomas). Growth of cultured human epidermal cells into multiple epithelia suitable for grafting. Proc Natl Acad Sci 1979;76:5655-68.

3. O'Connor EN., Mulliken JB., Banks-Schlegel S, Kehinde O. Grafting of burns with cultured epithelium prepared from autologous epidermal cells. Lancet 1981; 1:75-8.

4. De Luca M., Albanese E, Megna M, y cols. Evidence that human oral epithelium reconstituted in vitro and transplanted onto patients with defects in the oral mucosa retains the properties of the donor site. Transplantation 1990;50: 454-59.

5. Gallico GC, O'Conor NE., Compton CC, et al. Permanent coverage of large burn wounds with autologous cultured human epithelium. N Engl / Med 1984; 311:44851.

6. Pellegrini G, Bondanza S, Guerra L, De Luca M. Cultivation of human keratinocyte item cells: current and future clinical applications. Med Biol Eng Comp 1998;36:778-90.

7. Ragoebar JM, Tomson AM, Scholma J. Blaauw EH. Use of culture mucosal grafts to cover defects caused by vestibuloplasty. J Oral Maxillofac Surg 1995;53:87278.

8. Lam KP, Cham SY, To WH. y cols. Development and evaluation of a new composite laser skin graft. / Traumatol 1999;47:918-22.

9. Bohnert A, Hormung J, MacKenzie IC, Epithelio- mesenchimal interactions control basement membrane production and diferentiation in cultured and transplanted mouse keratinocytes. Cell Tissue Res 1986;244:413-29.

10. Bell E, Ehrlich NP, Buttle DJ. Aliving tissue formed in vitro and accepted as a full thickness skin equivalent. Science 1981;211:1052-56.

11. Worst PKM, MacKenzie IC, Fusenig NE. Reformation of organized epidermal structure by transplantation of suspensions and cultures of epidermal and dermal cells. Cell Tissue Res 1982;225:65-9.

12. Heck EL, Bergstresser PR, Baxter CR. Composite skin graft: frozen dermal allografts support the engraftment and expansion of autólogous epidermia. / Traumatol 1985;25:106-11.

13. Odioso LL, Doyle MJ, Quinn KW, Bartel RL, Zimber MP. Developement and caracterization of an in vitro gingival epithelial model. J Periodontol Res 1995;30:210-9.

14. Moriyama T, Asahina I, Ishii M y cols. Development of composite cultured oral mucosa utilizing collagen sponge matrix and contracted collagen gel: a preliminary study for clinical applications. Tissue Eng 2001;7:415-27.

15. Barrandon Y, Li V, Green H. New techniques for the grafting of cultured human epidermal cells onto athymic animals. J Investig Med 1988;91:315-18.

16. Fabre JW, Cullen PR. Rejection of cultured keratinocyte allografts in the rat. Transplantation 1989;48:306-15. implantation.

The present study shows that collagen gel was a good substrate for the growth of fibroblasts and oral keratinocytes. Synthesis of the gel was simple and predictable. Its management was extraordinarily easy and no exceptional precautions were necessary. However, marked retraction occurred and it was difficult to obtain a large amount of tissue, which was one of the objectives of the technique. Nonetheless, we also observed that the retraction process ceased when the graft is implanted and the grafted tissue conserved its diameter when the animals were killed.

\section{Acknowledgements}

We would like to thank the Spanish Society of Oral and Maxillofacial Surgery and Industrias Tarma, S.A. for supporting our work (Dr. Gómez Iglesias Basic Research Grant),

as well as Ficyt (Eva García Perez) and MBA (Verónica García Díaz) for their technical support. 
17. Izumi K, Feinberg SE, lida A, Yoshizawa M. Intraoral grafting o fan ex vivo produced oral mucosa equivalent: a preliminary report. Int J Oral Maxillofac Surg 2003;32:188-97.

18. Bodner L, Grossman N. Autologous cultured mucosal graft to cover large intraoral mucosal defects: a clinical study. J Oral Maxillofac Surg 2003;61:169-73.

19. Medalie DA, Erming SA, Tompinks RG, Yarmush ML, Krueger GG, Morgan JR. Evaluation of human skin reconstituted from composite grafts of cultured keratinocytes and human acellular dermis transplanted to atimic mice. J Investigat Dermatol 1996;107:121-7.

20. Wright KA, Nadire KB, Busto P, Tubo R, McPherson JM, Wentworth R. Alternative delivery of keratinocytes using a poliuretane membrane and the implications for its use in the treatment of full-thickness burn injury. Burns 1998;24:7-21.
22. Ueda M, Ebata K, Kaneda T. In vitro fabrication of bioartificial mucosa for reconstitution of oral mucosa: basic research and clinical application. Ann Plast Surg 1991;27:540-9.

23. Meana A., Iglesias J, Del Rio M, Larcher F, Madrigal B, Fresno MF. Large surface of cultureed human epithelium obtained on a dermal matrix based on live fibroblast-containing fibrin gels. Burns 1998;24: 621-30.

24. Lindberg K, Rheinwald JG. Three distinct keratinocyte subtypes identified in human oral epithelium by their patterns of keratin expression in culture and xenografts. Differentiation 1990;45:230-41.

25. Loro LL, Dimba EA, Vintermyr OK, Johannessen AC. Crucial effects of fibroblasts and keratinocyte growth factor on morphogenesis of reconstitued human oral epithelium. J Invest Dermatol 2003;121: 1479-86. 